Article

\title{
Impact of Zn Nanoparticles Synthesized via Green and Chemical Approach on Okra (Abelmoschus esculentus L.) Growth under Salt Stress
}

\author{
Sara Zafar ${ }^{1, *}$, Zuhair Hasnain ${ }^{2}\left(\mathbb{D}\right.$, Nazia Aslam ${ }^{1}$, Saqib Mumtaz ${ }^{3}{ }^{(D}$, Hawa ZE Jaafar ${ }^{4, *}$, \\ Puteri Edaroyati Megat Wahab ${ }^{4}$, Mughal Qayum ${ }^{5}$ and Alexe Nicolae Ormenisan ${ }^{6}$
}

check for

updates

Citation: Zafar, S.; Hasnain, Z.; Aslam, N.; Mumtaz, S.; Jaafar, H.Z.; Wahab, P.E.M.; Qayum, M.; Ormenisan, A.N. Impact of Zn Nanoparticles Synthesized via Green and Chemical Approach on Okra (Abelmoschus esculentus L.) Growth under Salt Stress. Sustainability 2021, 13, 3694. https://doi.org/10.3390/ su13073694

Academic Editor: Carlos M. Correia

Received: 7 January 2021

Accepted: 12 February 2021

Published: 26 March 2021

Publisher's Note: MDPI stays neutral with regard to jurisdictional claims in published maps and institutional affiliations.

Copyright: (c) 2021 by the authors. Licensee MDPI, Basel, Switzerland. This article is an open access article distributed under the terms and conditions of the Creative Commons Attribution (CC BY) license (https:/ / creativecommons.org/licenses/by/ $4.0 /)$.
1 Department of Botany, Government College University Faisalabad, Faisalabad, Punjab 38000, Pakistan; muhammadhader27@gmail.com

2 Department of Agronomy, PMAS Arid Agriculture University, Punjab Rawalpindi 46000, Pakistan; zuhair@uaar.edu.pk

3 Department of Biosciences, COMSATS University Islamabad, Islamabad Capital Territory 45550, Pakistan; saqib.mumtaz@comsats.edu.pk

4 Department of Crop Science, Faculty of Agriculture, Universiti Putra Malaysia, Seri Kembangan 43400, Malaysia; putri@upm.edu.my

5 Department of Pharmacy, Kohat University of Science and Technology, Kohat 26000, Pakistan; mu_afridii@yahoo.com

6 Department of Food and Tourism Engineering and Management, Transilvania University of Brasov, 500036 Brasov, Romania; nickorme@unitbv.ro

* Correspondence: sarazafar@gcuf.edu.pk (S.Z.); hawazej@gmail.com (H.Z.J.); Tel.: +92-3-356-626-966 (S.Z.)

Abstract: The study investigated the green and chemical approaches for the preparation of $\mathrm{Zn}$ nanoparticles and their effect on the growth of okra plants under saline conditions. The leaf extract of Sorghum bicolor L. was used for the green synthesis of zinc nanoparticles (Zn-GNPs). Zinc nanoparticles (Zn-NPs) were also produced by the co-precipitation method (Zn-CNPs). The synthesized NPs were characterized by UV-visible spectroscopy, X-ray diffraction (XRD) and Fourier-transform infrared spectroscopy (FTIR) and were applied foliarly in the range of $0.1 \%, 0.2 \%, 0.3 \%$ on okra plants. A marked increase in the shoot and root fresh and dry weight $(\mathrm{g})$ and chlorophyll contents were observed under normal and saline conditions. An increase in antioxidant activity was observed under saline conditions. However, the foliar application of $0.3 \% \mathrm{Zn}$-GNPs was helpful in the regulation of the antioxidant defense system under a saline environment. Based on the results, it can be concluded that the use of Zn-GNPs is the most promising eco-friendly approach in mitigating salinity stress.

Keywords: zinc nanoparticles; biological synthesis; sorghum extract; salinity stress; growth; okra

\section{Introduction}

Salt stress exerts drastic effects on plants in terms of decreasing productivity [1]. Physiological processes affected by the salinity stress include modification of mineral nutrition, ion balance, water status, photosynthetic efficiency and stomatal behavior. Salinity affects plant growth by affecting its physiology both at cellular as well as whole plant level through ionic and osmotic stress. A high concentration of salts in the root zone also affects the water availability or water potential due to very little water available to the plants [2]. The reduction of the water inside the plant leads to osmotic stress in plants. It also creates an imbalance in the uptake of useful ions like $\mathrm{K}^{+}, \mathrm{Ca}^{2+}$ and $\mathrm{Mg}^{2+}$ and replaces it with the uptake of toxic ions like $\mathrm{Na}^{+}$and $\mathrm{Cl}^{-}$. Various physiological processes affected by the salt stress include membrane permeability, membrane instability from $\mathrm{Ca}^{2+}$ and $\mathrm{K}^{+}$displacement by $\mathrm{Na}^{+}$, increase in respiration rate and ion toxicity, mineral distribution, decrease efficiency of photosynthesis and changes in plant growth. Decreased photosynthesis leads to the closure of the stomata, reduction in the $\mathrm{CO}_{2}$ assimilation inside the plant cells, reduction in the leaf area and green pigments [3]. 
Salinity stress results in the production of reactive oxygen species (ROS), like $\mathrm{O}^{-2}$, $\mathrm{H}_{2} \mathrm{O}_{2}$, and $\mathrm{OH}$, which affects DNA, RNA and proteins, also damage meristem activity and destruct chlorophyll [4]. To alleviate the harmful impact of salinity stress, organic fertilizers are mostly used [5]. Nanotechnology is a discipline dealing with materials and systems, including their structures and components with modified and improved characteristics, and opens up a wide range of opportunities in fields like medicine, pharmaceuticals, electronics, engineering and agriculture [6]. It has numerous benefits and uses and provides green and efficient alternatives for the management of plant productions. Nanotechnology helps plants to tolerate biotic and abiotic stresses, reduce environmental pollution by the use of nanoparticles (NPs) in an agricultural field. The NPs are particles with a size of less than $100 \mathrm{~nm}$ in at least one dimension. The green synthesis approach of producing nanoparticles from plants is economical and environmentally friendly [7]. The modern trend is the use of nanoparticles as nanofertilizer to help minimize the usage of toxic, harsh and expensive chemicals used commonly for plant growth [8]. The green approach of NPs synthesis depends upon the plant source and the organic compounds present in the plants [6]. The plants secrete some of the important phytochemicals that act as both cappings or stabilizing and reducing agents, which are provided separately in case of synthesis through chemical and physical methods [9]. The effect of the nanoparticles depend upon the concentration, $\mathrm{pH}$ and temperature [6].

Sorghum bicolor $\mathrm{L}$. is a source of functional and nutraceutical components due to the high antioxidant activity provided by phenolic acids, condensed tannins and anthocyanins, which can induce phase II detoxifying enzymes and inhibit the proliferation of carcinoma cell [10]. Due to the high drought and salt tolerance of sorghum, it can prove to be a beneficial crop in the future as water resources are limited and the world population continues to rise [11].

Abelmoschus esculentus L. (Okra) belongs to the family Malvaceae is an annual herbaceous plant grown in tropical and subtropical regions mostly. It is a source of vitamins, minerals, fats and carbohydrates [3]. Despite the high nutritional value and consumer demand, it is the yield per hectare. It is very low due to salinity [4]. The present investigation was carried out to evaluate the effect of $\mathrm{Zn}$ nanoparticles synthesized via green and chemical methods on the morphological and physiological behavior of okra seedlings under saline conditions.

\section{Materials and Methods}

The leaves of Sorghum bicolor L. were washed with distilled water three times. Dried homogeneous $10 \mathrm{~g}$ leaves censored into many sections were soaked in $90 \mathrm{~mL}$ of distilled water. The leaves were kept boiling at $90^{\circ} \mathrm{C}$ for $20 \mathrm{~min}$; the extract was collected and stored at $4{ }^{\circ} \mathrm{C}[12]$.

\subsection{Preparation of Zn NPs (Green Synthesis Approach)}

Zinc nanoparticles were prepared by adding $20 \mathrm{~mL}$ of the filtrate in $80 \mathrm{~mL}$ of $1 \mathrm{mM}$ $\mathrm{ZnSO}_{4} \cdot 7 \mathrm{H}_{2} \mathrm{O}$ solution. The solution was then sonicated for about $60^{\circ} \mathrm{C}$ for $1 \mathrm{~h}$. A change in the color to yellow indicated the formation of zinc nanoparticles (Zn-GNPs) [13].

\subsection{Preparation of Zn NPs (Chemical Synthesis; Co-precipitation Method)}

For the chemical synthesis of $\mathrm{Zn}$ nanoparticles, $0.1 \mathrm{M}$ of $\mathrm{ZnSO}_{4} \cdot 7 \mathrm{H}_{2} \mathrm{O}$ solution was added in $0.2 \mathrm{M} \mathrm{NaOH}$ solution. The solution was placed in a beaker over a hot plate at $55^{\circ} \mathrm{C}$ and $750 \mathrm{rpm}$. The solution was mixed for about $20 \mathrm{~min}$. The appearance of a white milky solution indicated the formation of Zn nanoparticles (Zn-CNPs) [14].

\subsection{Characterization}

The diameter of zinc nanoparticles (Zn NPs) was calculated by using the X-ray diffraction by Scherrer's equation

$$
\mathrm{t}=\mathrm{k} \lambda / \mathrm{B} \cos \theta,
$$


where, $\mathrm{K}=(0.92), \mathrm{t}=$ crystal size, $\lambda=(1.5418 \AA)$.

$X$-ray diffraction technique was used to analyze the structure and particle size of synthesized nanoparticles both via green and chemical approaches.

\subsection{Fourier Transform Infrared Spectroscopy (FTIR)}

The chemical nature of zinc nanoparticles was observed by the Fourier-transform infrared spectroscopy technique (FTIR RX1-PerkinElmer) in the wavelength range $4000-400 \mathrm{~cm}^{-1}$ [13].

\subsection{Seed Material and Germination}

Okra seeds for sowing were obtained from the Ayub Agricultural Research Institute, Faisalabad. Seeds were sterilized with $15 \%$ sodium hypochlorite for $15 \mathrm{~min}$ and washed thoroughly with distilled water. Ten seeds of okra were sown in plastic pots containing $8 \mathrm{~kg}$ of soil (soil properties-Table 1), placed in a wirehouse at the experimental station of Government College University Faisalabad, Pakistan. The required level of salinity $\left(10 \mathrm{dSm}^{-1}\right)$ was obtained after two weeks of sowing by supplying $\mathrm{NaCl}$ solution to the soil.

Table 1. Soil properties.

\begin{tabular}{cccc}
\hline & \multicolumn{2}{c}{ Soil Characteristics } \\
\hline Soil texture & Sandy Loam & Cl-(meq/L) & $\mathbf{2 . 2 2}$ \\
\hline ECe $\left(\mathrm{dS} \mathrm{m}^{-1}\right)$ & 0.40 & $\mathrm{Ca}+\mathrm{Mg}(\mathrm{meq} / \mathrm{L})$ & 4.1 \\
$\mathrm{pH}$ & 7.01 & $\mathrm{Na}+(\mathrm{ppm})$ & 2.71 \\
Organic matter $(\%)$ & 0.27 & Soluble $\mathrm{K}+(\mathrm{ppm})$ & 21 \\
Saturation $(\%)$ & 36 & Total N $(\%)$ & 0.061 \\
$\mathrm{CO}_{3}{ }^{2-}(\mathrm{meq} / \mathrm{L})$ & $\mathrm{Nil}$ & Available P $(\mathrm{ppm})$ & 8.21 \\
$\mathrm{HCO}_{3}{ }^{-}(\mathrm{meq} / \mathrm{L})$ & 2.74 & Zn $(\mathrm{ppm})$ & 1.2 \\
\hline
\end{tabular}

Exogenous foliar application of Zn-GNPs and Zn-CNPs were applied on 45-day-old okra plants at $0.1 \%, 0.2 \%$ and $0.3 \%$ concentration. The collected data were statistically analyzed by Statistix version 8.1. Microsoft Excel-2007 was used to assess mean and standard errors; the difference of means was calculated at a $5 \%$ probability level by the least significant difference (LSD) test.

Three plants from each plot were harvested 15 days after NPs application for the determination of plant growth, antioxidants and MDA contents. Plants were oven-dried for $72 \mathrm{~h}$ for dry weight.

\subsection{Pigment Analysis}

The method of [15] was used for the extraction of chlorophyll contents and was calculated using the formula [16]. By using the following formulae, Chla (chlorophyll), $\mathrm{Chlb}$, and carotenoid contents were calculated

$$
\begin{aligned}
& \text { Chla }=\left(12.7(\text { OD 663 })-2.69(\text { OD 645) }) \times \frac{\mathrm{V}}{1000} \times \mathrm{W}\right. \\
& \text { Chlb }=\left(22.9(\text { OD 645 })-4.68(\text { OD 663) }) \times \frac{\mathrm{V}}{1000} \times \mathrm{W}\right.
\end{aligned}
$$

$$
\text { Carotenoid }\left(\mathrm{g} \mathrm{mL}^{-1}\right)=\text { Acar } / \mathrm{Em} \times 100
$$

where Acar $=$ OD $480+0.114(\mathrm{OD} 663)-0.68(\mathrm{OD} 645), \mathrm{Em} \times 100=2500, \mathrm{OD}=$ optical density, $\mathrm{V}=$ sample extract volume and $\mathrm{W}=$ sample weight.

\subsection{Antioxidant Enzymes}

Leaves were homogenized in $50 \mathrm{mM}$ phosphate buffer $7.8 \mathrm{pH}$ and centrifuged at $15,000 \times g$ for $20 \min \left(4^{\circ} \mathrm{C}\right)$. For determining enzyme activity, the supernatant was used. 
Superoxide dismutase (SOD), catalase (CAT) and peroxidase (POD) were analyzed by using a spectrophotometer.

\subsection{Catalase (CAT)}

The activity of CAT was determined in $3 \mathrm{~mL} 7.0 \mathrm{pH}$ phosphate buffer $(50 \mathrm{mM})$ having $5.9 \mathrm{mM} \mathrm{H}_{2} \mathrm{O}_{2}$ and enzyme extract $(0.1 \mathrm{~mL})$ as reported by [17]. The activity of CAT enzyme measured at $240 \mathrm{~nm}$ absorbance past each $20 \mathrm{~s}$. Every unit of activity is a change of 0.01 unit $\min ^{-1}$.

\subsection{Peroxidase (POD)}

Peroxidase is the peroxidation as an electron donor of hydrogen peroxide and guaiacol [17]. Add $50 \mathrm{mM}$, phosphate buffer ( $\mathrm{pH}$ 5), $20 \mathrm{mM}$ of guaiacol, $\mathrm{H}_{2} \mathrm{O}_{2}(40 \mathrm{mM})$ and $0.1 \mathrm{~mL}$ enzyme extract. Enhanced absorbance at $470 \mathrm{~nm}$ by tetra guaiacol formed measured after each $20 \mathrm{~s}$. A single enzyme unit was responsible for enhancing the OD value of $0.01 \mathrm{~min}^{-1}$.

\subsection{Superoxide Dismutase Activity}

SOD activity [18] (Giannopolitis and Ries, 1977) was measured as the inhibitionreduction of nitroblue tetrazolium (NBT) by xanthine oxidase. Absorbance was measured by UV-visible (IRMECO U2020) spectrophotometer at $560 \mathrm{~nm}$. A single unit activity exhibited $50 \%$ photochemical inhibition of NBT.

\subsection{Statistical Analysis}

The data regarding physico-biochemical attributes was analyzed by the software program Statistix version 8.1. Microsoft Excel-2007 was used to evaluate mean and standard errors; the difference of means was calculated at a $5 \%$ probability level by least significant difference (LSD) tests.

\section{Results}

\subsection{Characterization}

The structure and the size of the nanoparticles obtained from the powder XRD diffraction technique. The XRD shows the noticeable peaks at $2 \theta(36.2,31.7,62.8,34.4,56.6$, 47.5, 67.9 and 69.1 for sample A and peaks for sample B are 36.2, 31.7, 34.4, 47.5, 56.5, 62.8. Peaks (Figure 1) confirmed the crystalline structure of the $\mathrm{ZnO}$ nanoparticles. Sharp and clear peaks shown by the samples indicate the formation of the crystalline structure of the nanoparticles.

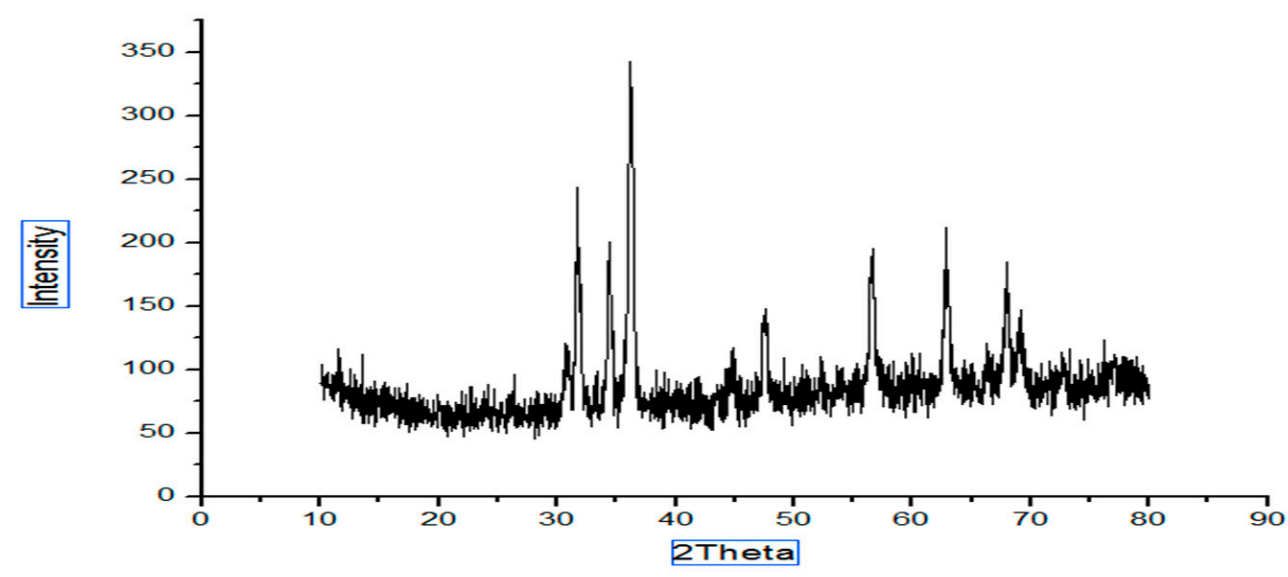

Figure 1. XRD (green synthesis approach). 
Scherrer equation was used to find out the crystalline size of the nanoparticles

$$
\mathrm{D}=\frac{\mathrm{k} \lambda}{\beta \operatorname{Cos} \theta}
$$

where $D$ is the crystalline size, $\lambda$ is the wavelength, $\beta$ is the full-width half-maximum (FWHM) of the $\mathrm{ZnO}$, and $\theta$ is the diffraction angle. The calculated size of the prepared $\mathrm{ZnO}$ nanoparticles via the green approach (Figure 1) appeared to be $17 \mathrm{~nm}$, and the particle size of the chemically synthesized nanoparticles was $40 \mathrm{~nm}$ (Figure 2).

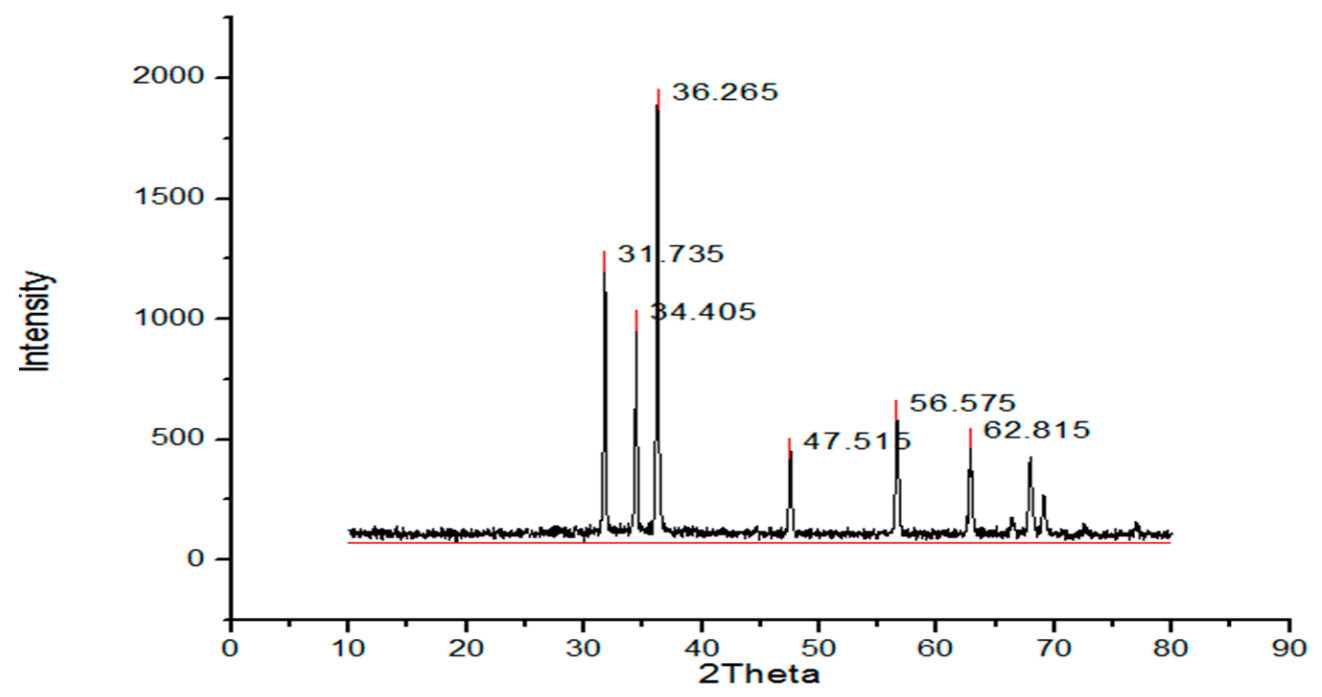

Figure 2. XRD (chemical synthesis approach).

The absorption peak shown by Sample A (Figure 3) Zn- GNPs was $359.71 \mathrm{~nm}$. Whereas the absorption peak of Sample B (Figure 4) shown by Zn-CNPs was $399.14 \mathrm{~nm}$. The absorption peak shown by the nanoparticles is basically the intrinsic bandgap absorption of $\mathrm{Zn}$ nanoparticles, which is due to the transition of electrons from valance to conduction band. The bandgap energy of the ZnO NPs is calculated by using the following formula,

$$
\mathrm{E}=\frac{\mathrm{hc}}{\lambda}
$$

where $\mathrm{h}$ is the plank's constant $\mathrm{h}=6.626 \times 10-34 \mathrm{Js}, \mathrm{c}$ is the velocity of light $3 \times 108 \mathrm{~m} / \mathrm{s}$, and $\lambda$ is $359.71 \mathrm{~nm}$ for sample $A$ and $399.14 \mathrm{~nm}$ for sample B. The bandgap energy for sample $\mathrm{A}$ is $3.4 \mathrm{eV}$, and for sample $\mathrm{B}$ is $3.1 \mathrm{eV}$.

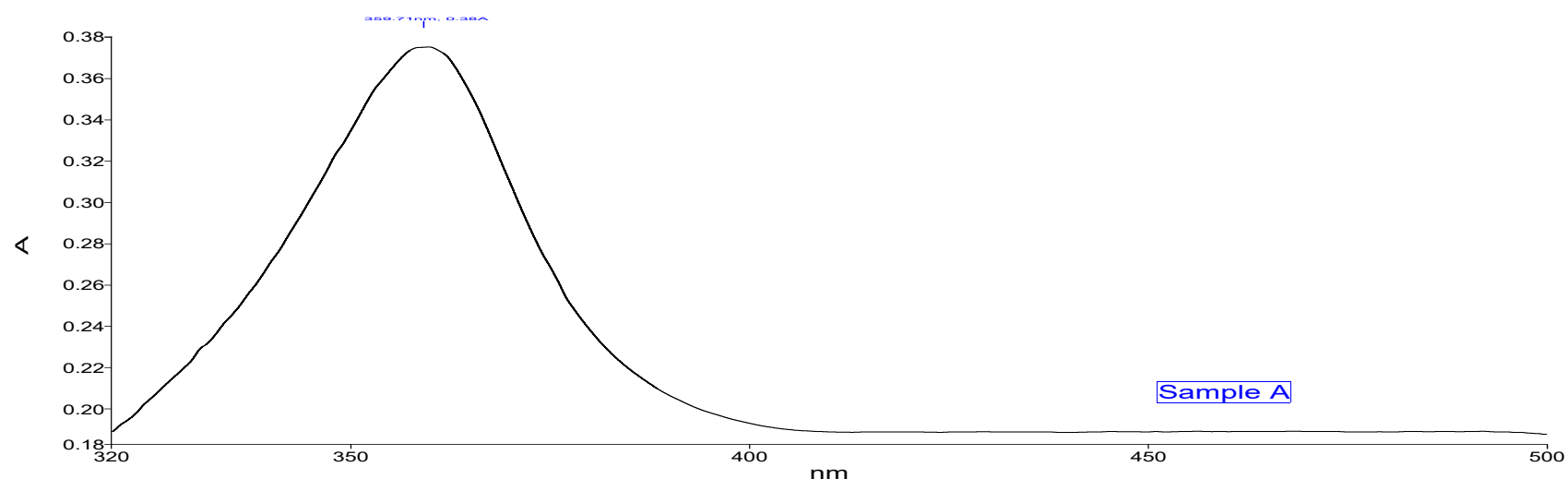

Figure 3. UV-visible spectroscopy (green approach). 


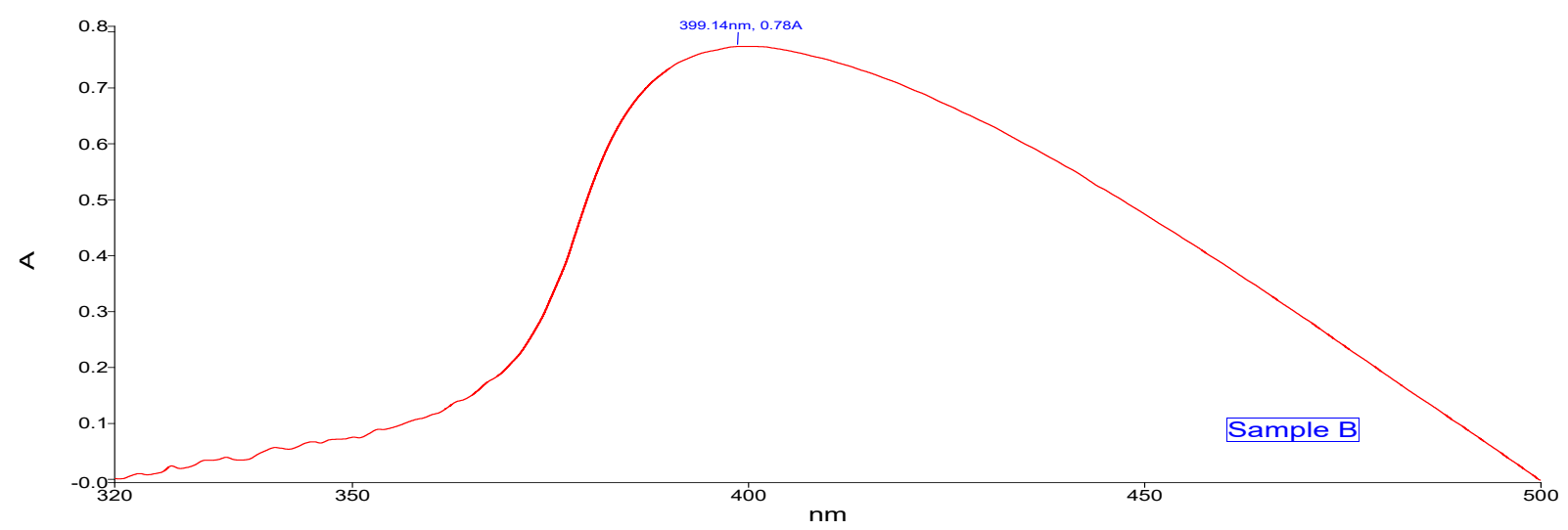

Figure 4. UV-visible spectroscopy (chemical approach).

\subsection{FTIR (Green Approach)}

Sample A (Zn-GNPs) (Figure 5) using Sorghum bicolor leaf extract showed an absorption band at $3271.18 \mathrm{~cm}^{-1}$ representing $\mathrm{O}-\mathrm{H}$ stretching of alcohol. The absorption peak located at $1642.55 \mathrm{~cm}^{-1}$ represents the $\mathrm{C}=\mathrm{C}$ bonding of alkene. Stretching vibrations at $1377.61 \mathrm{~cm}^{-1}$ showed the $\mathrm{C}-\mathrm{H}$ stretching of the methyl group.

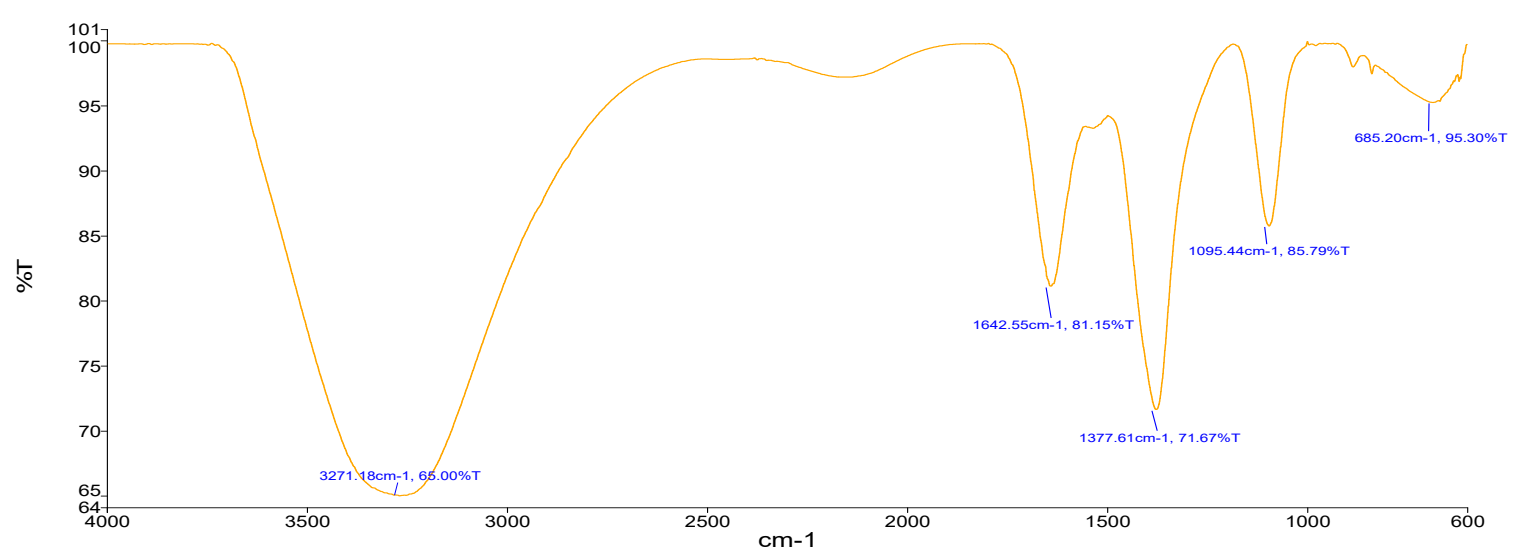

Figure 5. FTIR (green approach).

The stretching at $1095.44 \mathrm{~cm}^{-1}$ showed vibrations of C-O bonding of polysaccharides. The stretching at $685.20 \mathrm{~cm}^{-1}$ showed C-Cl strong bond.

For sample B (Zn-CNPs), the following stretching was obtained. The stretching obtained at $3391.55 \mathrm{~cm}^{-1}$ (Figure 6) showed O-H bonding as observed by Eleumali et al. [19]. Stretching at $1637.66 \mathrm{~cm}^{-1}$ showed $C=C$ alkene bonding. The stretching at $1387.55 \mathrm{~cm}^{-1}$ showed C-H methyl bonding. Stretching at $1088.14 \mathrm{~cm}^{-1}$ showed bonds of polysaccharides. The stretching at $619.9 \mathrm{~cm}^{-1}$ showed $\mathrm{C}-\mathrm{Cl}$ bonding. 


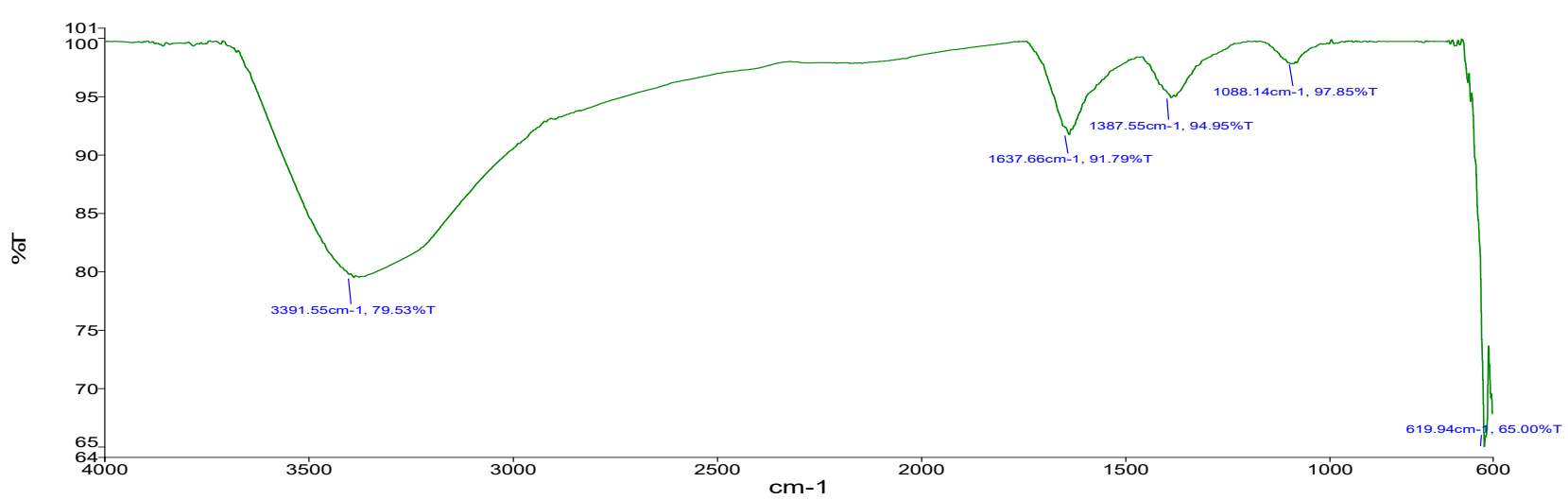

Figure 6. FTIR (chemical approach).

After the characterization of NPs, the response of foliar application of nanoparticles under saline and non-saline conditions on the growth of okra plants was evaluated. The application of NPs exerted a positive influence on growth traits. Salinity significantly decreased growth attributes and chlorophyll contents (Figures 7 and 8) in okra plants. Application of $0.3 \% \mathrm{Zn}-\mathrm{GNPs}$ and $0.2 \% \mathrm{Zn}$-CNPs exerted a positive influence on the shoot length of okra. Significant differences were observed in root length, shoot fresh and dry weight and chlorophyll contents. Maximum Chla was noted by an exogenous spray of $0.3 \%$ followed by $0.2 \%$ Zn-GNPs and Zn-CNPs. A 32\% reduction in Chlb contents under salinity stress conditions was observed in okra plants. However, foliarly applied NPs prevented damage caused by stress on chlorophyll contents. A maximum increase in Chlb contents was observed at $0.3 \%$, followed by $0.2 \% \mathrm{Zn}$-GNPs and Zn-CNPs under saline conditions. However, foliar application of NPs at $0.3 \%$ showed a more positive effect in minimizing the harmful effect of salinity on Chla, Chlb and carotenoids in okra plants. An enhancement in antioxidant activities was recorded under salinity stressed okra plants. Zinc Nps prepared from Sorghum bicolor leaf extract at a concentration of $0.3 \%$ under salinity stress maintained the catalase enzyme activity at 12.68 unit $\min ^{-1}$ in okra plants. The enzymatic antioxidants in okra plants revealed maximum activity under salinity stress alone and helped in mitigating stress at $0.3 \%$ followed by $0.2 \%$ Zn-GNPs and Zn-CNPs. 


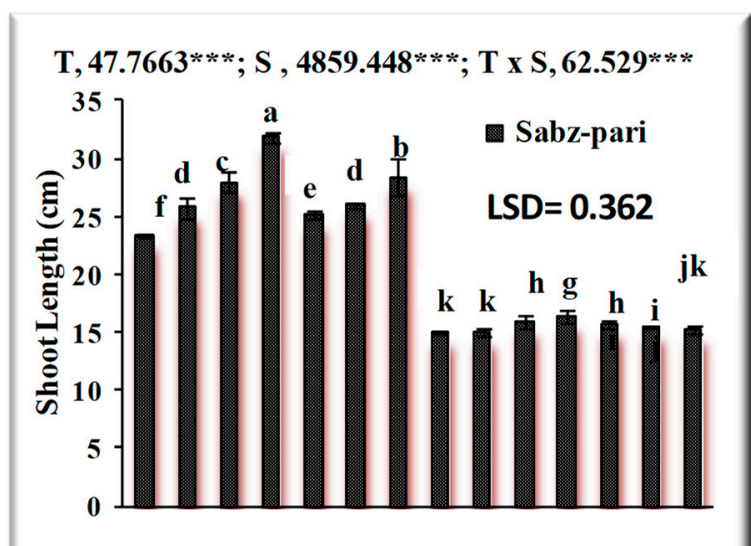

$T, 26.739 * * ; S, 796.347 ; T \times S, 17.786 * * *$

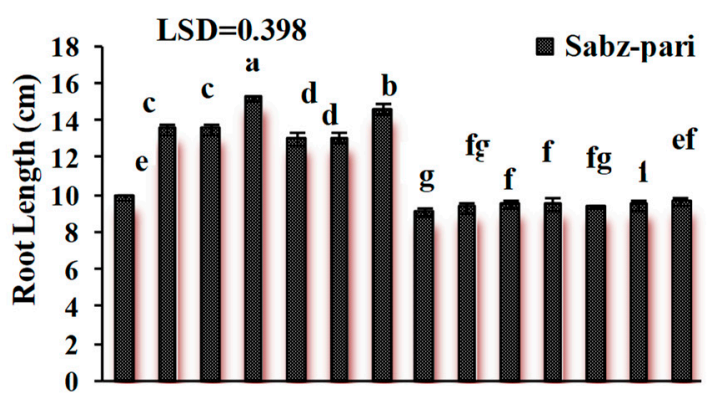

\section{$\mathrm{T}, 0.802^{*} ; \mathrm{S}, 3.579^{* * *} ; \mathrm{T} \times \mathrm{S}, 0.345 \mathrm{~ns}$}

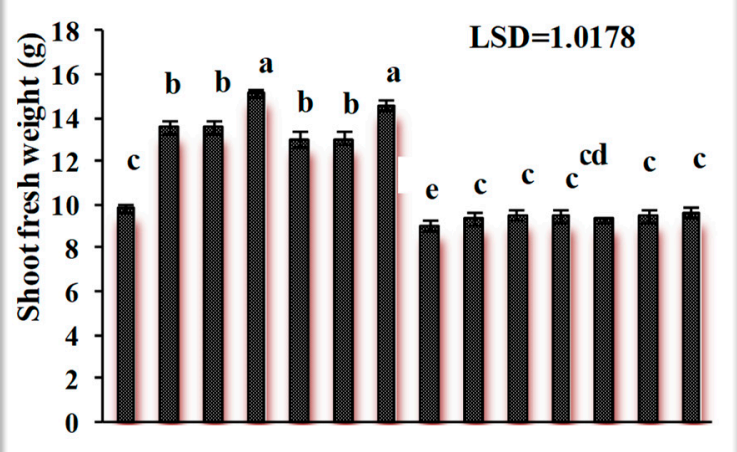

T, 0.063ns; S, 0.307*; ${ }^{*}$ x S, 0.039ns

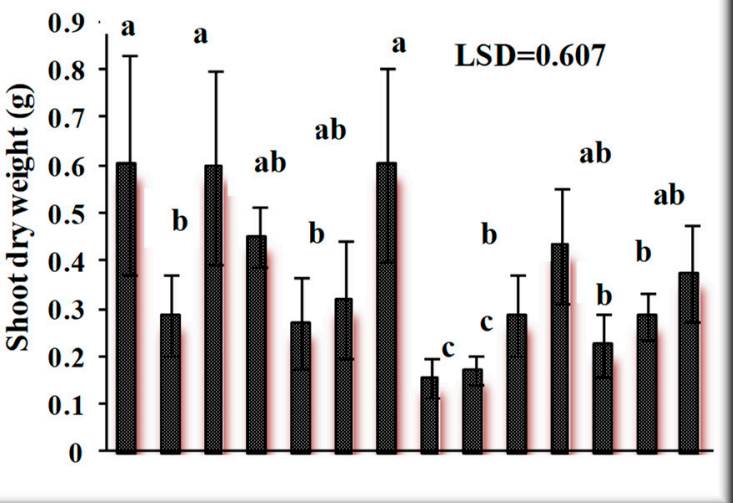

T, 0.07ns; S, 3.80ns; T x S, 0.058ns
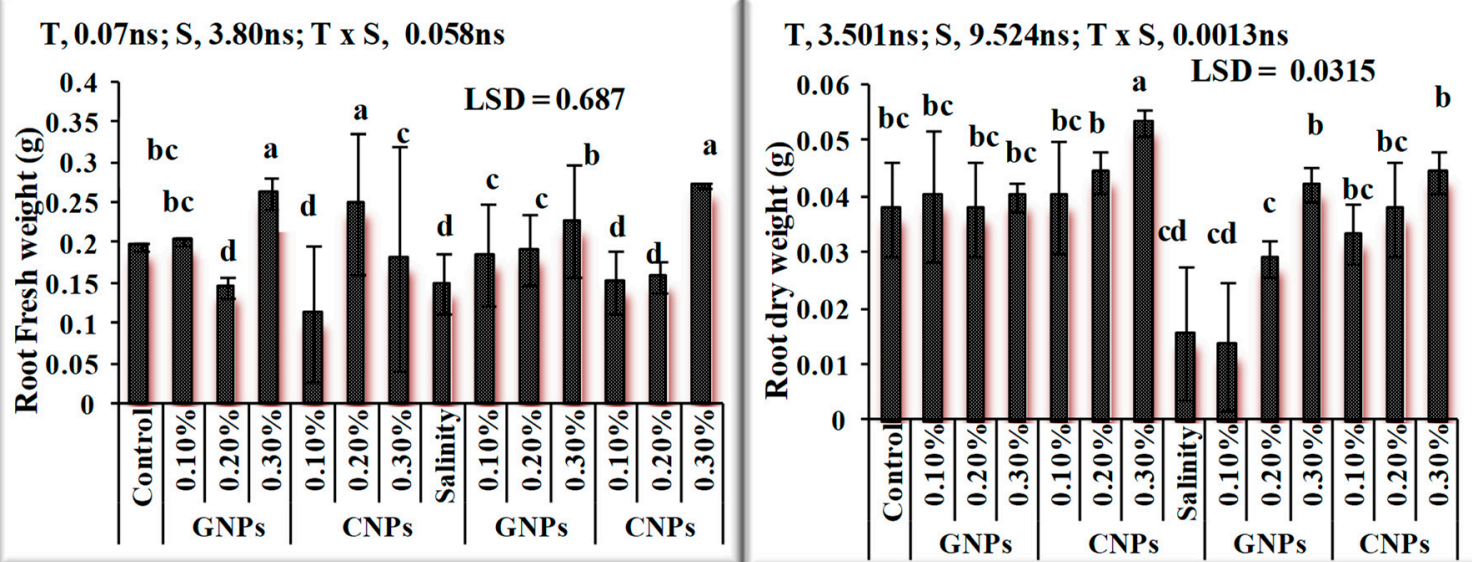

Figure 7. Effect of green synthesized and chemically synthesized Zn nanoparticles on growth attributes of okra under saline and non-saline conditions. ${ }^{* * *}$ Significant at 0.001 and ${ }^{*}$ at 0.05 level of significance at $5 \%$ probability. 


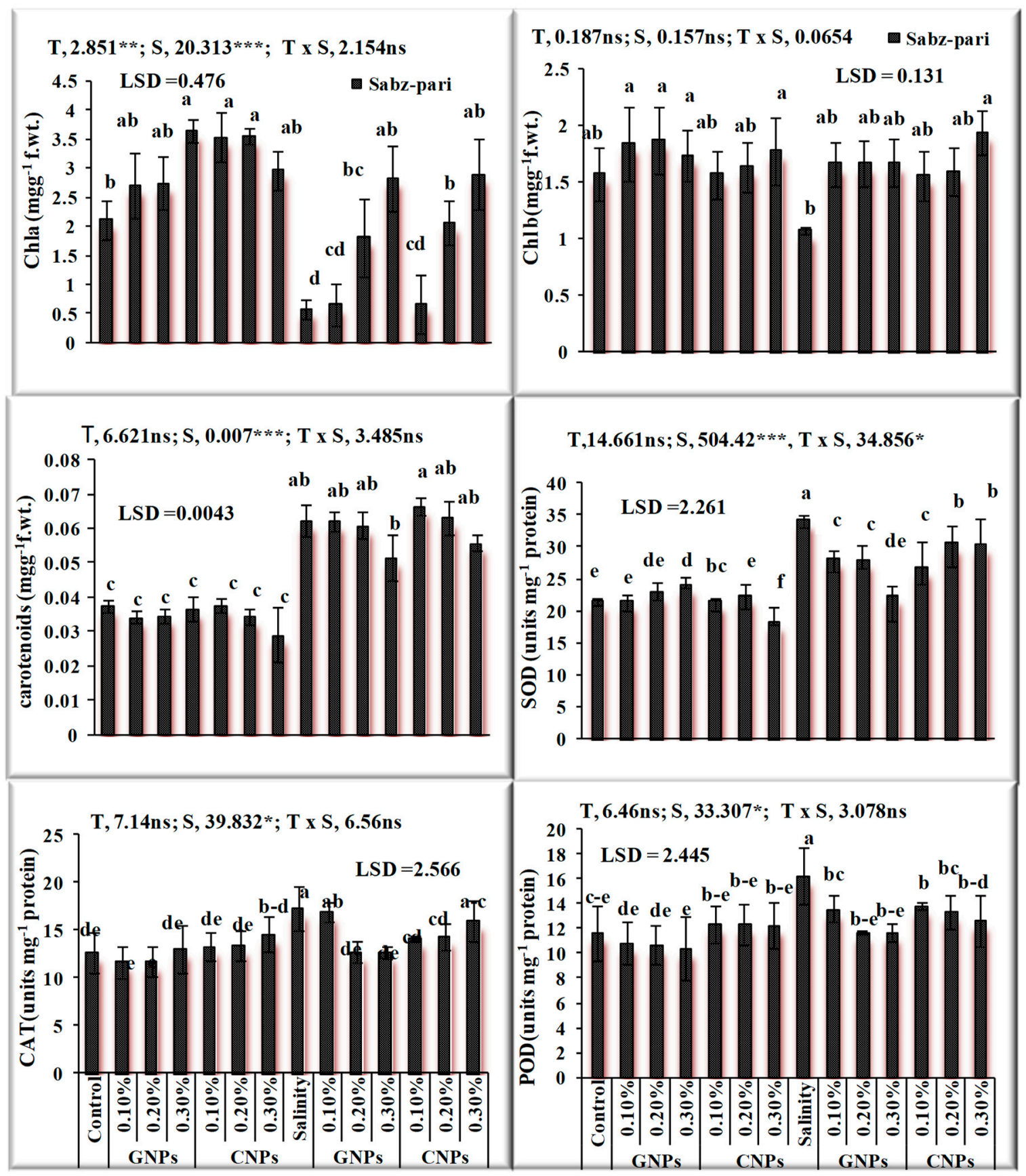

Figure 8. Effect of green synthesized and chemically synthesized Zn nanoparticles on antioxidant activities of okra under saline and non-saline conditions ${ }^{* * *},{ }^{* *}$ Significant at $0.001,0.01$ and $*$ at 0.05 level of significance at $5 \%$ probability.

\section{Discussion}

Sorghum bicolor leaf extract was used for the preparation of eco-friendly Zn-GNPs as the biomolecules in the leaf extract are effective in stabilizing the Zn NPs [6]. A yellow color appearance in extract color with $\mathrm{ZnSO}_{4}$ solution confirmed the formation of $\mathrm{Zn}$ GNPs [13]. However, the appearance of a white milky solution indicated the formation of $\mathrm{Zn}$ nanoparticles prepared through the co-precipitation method [14].

By using XRD analysis, the formation of Zn-GNPs and Zn-CNPs was determined to have an average size of $17 \mathrm{~nm}$ and $40 \mathrm{~nm}$. The various functional groups for synthesized nanoparticles were detected by FT-IR spectroscopy analysis. The optical properties of the samples were investigated by measuring the UV-visible spectroscopy [20]. The main peaks showed primary and secondary amides, and amines, proteins, alcohols, aromatic hydrocar- 
bons, aldehydes, ketones and carboxylic acids, as well as stretching and bending vibrations, proved that all these are connected with Zn-NPs [9]. The exogenous foliar application of Sorghum bicolor leaf extract-mediated Zn-GNPs increased the physicochemical attributes in okra plants.

Salinity stress reduced the growth of okra plants, leading to stunted plant growth. A decrease in the growth of roots was observed under salinity stress; it is due to a reduction in water use efficiency, leaf water potential and transpiration rate under salt stress. A reduction in chlorophyll contents was observed underwater stress. The reduction is attributed to a stress-induced decrease in the photosynthetic apparatus of plants, as reported by Zafar et al. [1]. It is reported by Kaya et al. [21] that plants under stress conditions close their stomata to retain the amount of water in the leaves, which leads ultimately decreases the number of photosynthetic products.

An increase in growth by foliar application of Zn NPs may be attributed to the crucial role of zinc on the biological and metabolism activity of plants such as stimulating enzymes activities, cell elongation and enlargement, nitrogen metabolism, photosynthetic pigments, maintaining the membranes structural stability of the plant cells and accumulation of the phospholipids [22,23]. The Zn NPs possess the ability to penetrate the plant cell through the natural nanopores (stomata) in the leaves and improve plant metabolic activities and consequently results in higher plant production. The foliar supply of Zn NPs releases the $\mathrm{Zn}$ ion slowly and helps to avoid toxicity by sudden uptake of $\mathrm{Zn}$ by plants at a high concentration [24].

A decrease in chlorophyll contents under salt stress may be due to membrane deterioration [25]. Stress changes the size and number of chloroplasts, damage and injure the grana and thylakoids [26]. Our findings demonstrate that under salt stress, foliar application of NPs enhance the contents of chlorophyll $a, \mathrm{~b}$ and improved carotenoid contents. The prior study by Venkatachalam et al. [27] revealed similar results on the cotton plant (Gossypium hirsutum L.). Nanoparticles (NPs) improve the functioning efficiency of photosynthetic systems [28]. Zn is a vital component for the development of protochlorophyllide and improves the chloroplast functioning and helps in repairs of photosystem II [29]. An enhancement in carotenoid contents may be related to the response of plants to oxidative damage [30]. The antioxidant enzymes CAT, POD and SOD, scavenge ROS- in plants and supply protection and defense to plant cells from the oxidative stress of reactive free radicals [31]. An increase in the antioxidant enzyme activities and antioxidant metabolism is one of the crucial ways to improve salinity tolerance in plants [32]. In the present work, our findings confirm that the applications of Zn GNPs and Zn CNPs improved the activities of SOD, POD and CAT in okra plants under salinity stress compared with the control plants. The application of Zn-NPs improved the values of antioxidant enzymes, and the results are in agreement with the findings of Rizwan et al. [33] on maize (Zea mays L.). Metal NPs inhibit ROS formation by improving the antioxidant activity of the plant cells [34]. The increase in catalase activity in plants treated with Zn-NPs suggests that NPs can effectively modify the enzyme activity.

\section{Conclusions}

It can be concluded from the study that exogenous spray of NPs significantly ameliorates the harmful effect of stress; however, the application of Zn-GNPs being an eco-friendly approach was more effective in mitigating stress.

Author Contributions: Conceptualization, S.M.; formal analysis, N.A.; investigation, M.Q.; methodology, Z.H.; resources, H.Z.J. and P.E.M.W.; software, A.N.O.; supervision, S.Z. All authors have read and agreed to the published version of the manuscript.

Funding: This research received no external funding.

Institutional Review Board Statement: Not applicable.

Informed Consent Statement: Not applicable. 
Data Availability Statement: Not applicable.

Acknowledgments: Authors extend thanks to their respective institutes and universities.

Conflicts of Interest: The authors declare no conflict of interest.

\section{References}

1. Zafar, S.; Akhtar, M.; Perveen, S.; Hasnain, Z.; Khalil, A. Attenuating the adverse aspects of water stress on wheat genotypes by foliar spray of melatonin and indole-3-acetic acid. Physiol. Mol. Biol. Plants 2020, 26, 1751-1762. [CrossRef] [PubMed]

2. Sonam, S.; Anirudha, R.; Subhash, C. Effect of short term salt stress on chlorophyll content, protein and activities of catalase and ascorbate peroxidase enzymes in pearl millet. Am. J. Plant Physiol. 2014, 9, 32-37.

3. Shahid, M.A.; Pervez, M.A.; Balal, R.M.; Ahmad, R.; Ayyub, C.M.; Abbas, T.; Akhtar, N. Salt stress effects on some morphological and physiological characteristics of okra (Abelmoschus esculentus L.). Soil Environ. 2011, 30, 66-73.

4. Habib, N.; Ashraf, M.; Ali, Q.; Perveen, R. Response of salt stressed okra (Abelmoschus esculentus Moench) plants to foliar-applied glycine betaine and glycine betaine containing sugarbeet extract. South Afr. J. Bot. 2012, 83, 151-158. [CrossRef]

5. Naveed, M.; Sajid, H.; Mustafa, A.; Niamat, B.; Ahmad, Z.; Yaseen, M.; Kamran, M.; Rafique, M.; Ahmar, S.; Chen, J.-T. Alleviation of Salinity-Induced Oxidative Stress, Improvement in Growth, Physiology and Mineral Nutrition of Canola (Brassica napus L.) through Calcium-Fortified Composted Animal Manure. Sustainability 2020, 12, 846. [CrossRef]

6. Zafar, S.; Ashraf, A.; Ijaz, M.U.; Muzammil, S.; Siddique, M.H.; Afzal, S.; Andleeb, R.; Al-Ghanim, K.A.; Al-Misned, F.; Ahmed, Z. Eco-friendly synthesis of antibacterial zinc nanoparticles using Sesamum indicum L. extract. J. King Saud Univ. Sci. 2020, 32, 1116-1122. [CrossRef]

7. Iqbal, M.S.; Singh, A.K.; Singh, S.P.; Ansari, M.I. Nanoparticles and Plant Interaction with Respect to Stress Response. In Nanomaterials and Environmental Biotechnology; Springer: Cham, Switzerland, 2020.

8. Maroufpour, N.; Mousavi, M.; Abbasi, M.; Ghorbanpour, M. Biogenic Nanoparticles as Novel Sustainable Approach for Plant Protection. In Biogenic Nano-Particles and Their Use in Agro-Ecosystems; Springer: Singapore, 2020; pp. 161-172.

9. Ashraf, A.; Zafar, S.; Zahid, K.; Shah, M.S.; Al-Ghanim, K.A.; Al-Misned, F.; Mahboob, S. Synthesis, characterization, and antibacterial potential of silver nanoparticles synthesized from Coriandrum sativum L. J. Infect. Public Health 2019, 12, 275-281. [CrossRef]

10. Awika, J.M.; Yang, L.; Browning, J.D.; Faraj, A. Comparative antioxidant, antiproliferative and phase II enzyme inducing potential of sorghum (Sorghum bicolor) varieties. Lwt-Food Sci. Technol. 2009, 42, 1041-1046. [CrossRef]

11. Anami, S.E.; Zhang, L.M.; Xia, Y.; Zhang, Y.M.; Liu, Z.Q.; Jing, H.C. Sweet sorghum ideotypes: Genetic improvement of stress tolerance. Food Energy Secur. 2015, 4, 3-24. [CrossRef]

12. Saravanakkumar, D.; Sivaranjani, S.; Umamaheswari, M.; Pandiarajan, S.; Ravikumar, B. Green synthesis of ZnO nanoparticles using Trachyspermum ammi seed extract for antibacterial investigation. Der Pharma Chem. 2016, 8, 173-180.

13. Eya'ane Meva, F.; Segnou, M.L.; Ebongue, C.O.; Ntoumba, A.A.; Kedi, P.B.E.; Deli, V.; Etoh, M.-A.; Mpondo, E.M. Spectroscopic synthetic optimizations monitoring of silver nanoparticles formation from Megaphrynium macrostachyum leaf extract. Rev. Bras. De Farmacogn. 2016, 26, 640-646. [CrossRef]

14. El-Waseif, A.; El-Ghwas, D.; EL-Diwany, A. Zinc Oxide nanoparticles formation, characterization and biological approach. J. Innov. Pharm. Biol. Sci. 2017, 4, 39-43.

15. Arnon, D.I. Copper enzymes in isolated chloroplasts. Polyphenoloxidase in Beta vulgaris. Plant Physiol. 1949, 24, 1. [CrossRef] [PubMed]

16. Goodwin, T.W. Chemistry and Biochemistry of Plant Pigments; Academic Press: New York, NY, US, 1976.

17. Chance, B.; Maehly, A. The Assay of Catalases and Peroxidases. Available online: https://onlinelibrary.wiley.com/doi/10.1002/ 9780470110171.ch14 (accessed on 14 February 2021).

18. Giannopolitis, C.N.; Ries, S.K. Superoxide dismutases: I. Occurrence in higher plants. Plant Physiol. 1977, 59, 309-314. [CrossRef]

19. Elumalai, K.; Velmurugan, S. Green synthesis, characterization and antimicrobial activities of zinc oxide nanoparticles from the leaf extract of Azadirachta indica (L.). Appl. Surf. Sci. 2015, 345, 329-336. [CrossRef]

20. Veemaraj, T.; Mubeenabanu, A. Synthesis and Characterization of Nanoparticles Using Co-Precipitation Method: A Comparative Study. J. Chem. Pharm. Res. 2017, 9, 146-152.

21. Kaya, C.; Tuna, L.; Higgs, D. Effect of silicon on plant growth and mineral nutrition of maize grown under water-stress conditions. J. Plant Nutr. 2006, 29, 1469-1480. [CrossRef]

22. Sturikova, H.; Krystofova, O.; Huska, D.; Adam, V. Zinc, zinc nanoparticles and plants. J. Hazard. Mater. 2018, 349, 101-110. [CrossRef]

23. Mehrabani, L.V.; Hassanpouraghdam, M.B.; Shamsi-Khotab, T. The effects of common and nano-zinc foliar application on the alleviation of salinity stress in Rosmarinus officinalis L. Acta Sci. Pol. Hortorum Cultus 2018, 17, 65-73. [CrossRef]

24. Alabdallah, N.M.; Alzahrani, H.S. Impact of ZnO Nanoparticles on Growth of Cowpea and Okra Plants under Salt Stress Conditions. Biosci. Biotechnol. Res. Asia 2020, 17, 329-340. [CrossRef]

25. Silveira, J.A.; Carvalho, F.E. Proteomics, photosynthesis and salt resistance in crops: An integrative view. J. Proteom. 2016, 143, 24-35. [CrossRef] [PubMed] 
26. Hasan, R.; Kawasaki, M.; Taniguchi, M.; Miyake, H. The damage of root, leaf and chloroplast ultrastructure on maize seedlings caused by salinity stress. Earth Environ. Sci. 2018, 197, 012054. [CrossRef]

27. Venkatachalam, P.; Priyanka, N.; Manikandan, K.; Ganeshbabu, I.; Indiraarulselvi, P.; Geetha, N.; Muralikrishna, K.; Bhattacharya R.; Tiwari, M.; Sharma, N. Enhanced plant growth promoting role of phycomolecules coated zinc oxide nanoparticles with $\mathrm{P}$ supplementation in cotton (Gossypium hirsutum L.). Plant Physiol. Biochem. 2017, 110, 118-127. [CrossRef] [PubMed]

28. Singh, A.; Singh, N.; Hussain, I.; Singh, H.; Singh, S. Plant-nanoparticle interaction: An approach to improve agricultural practices and plant productivity. Int. J. Pharm Sci. Invent. 2015, 4, 25-40.

29. Salama, D.M.; Osman, S.A.; Abd El-Aziz, M.; Abd Elwahed, M.S.; Shaaban, E. Effect of zinc oxide nanoparticles on the growth, genomic DNA, production and the quality of common dry bean (Phaseolus vulgaris). Biocatal. Agric. Biotechnol. 2019, 18, 101083. [CrossRef]

30. Mohsenzadeh, S.; Moosavian, S.S. Zinc sulphate and nano-zinc oxide effects on some physiological parameters of Rosmarinus officinalis. Am. J. Plant Sci. 2017, 8, 2635-2649. [CrossRef]

31. El-Beltagi, H.S.; Ahmed, S.H.; Namich, A.A.M.; Abdel-Sattar, R.R. Effect of salicylic acid and potassium citrate on cotton plant under salt stress. Fresen. Environ. Bull. 2017, 26, 1091-1100.

32. Guilian, M.; Xing, X.; Zhaozhen, X. Advances in physiological and biochemical research of salt tolerance in plant. Chin. J. Eco-Agric. 2004, 12, 43-46.

33. Rizwan, M.; Ali, S.; ur Rehman, M.Z.; Adrees, M.; Arshad, M.; Qayyum, M.F.; Ali, L.; Hussain, A.; Chatha, S.A.S.; Imran, M. Alleviation of cadmium accumulation in maize (Zea mays L.) by foliar spray of zinc oxide nanoparticles and biochar to contaminated soil. Environ. Pollut. 2019, 248, 358-367. [CrossRef]

34. Ye, Y.; Medina-Velo, I.A.; Cota-Ruiz, K.; Moreno-Olivas, F.; Gardea-Torresdey, J.L. Can abiotic stresses in plants be alleviated by manganese nanoparticles or compounds? Ecotoxicol. Environ. Saf. 2019, 184, 109671. [CrossRef] 